\title{
Advances in current medication and new therapeutic approaches in epilepsy
}

\author{
Oruc Allahverdiyev ${ }^{1 *}$, Sara Dzhafar ${ }^{1}$, Mehmet Berköz $^{2}$, Metin Yıldırım ${ }^{3}$ \\ ${ }^{1}$ Department of Pharmacology, Van Yuzuncu Yil University, Faculty of Pharmacy, Van, Turkey \\ ${ }^{2}$ Department of Pharmaceutical Biotechnology, V an Yuzuncu Yil University, Faculty of Pharmacy, Van, Turkey \\ ${ }^{3}$ Department of Biochemistry, Mersin University, Faculty of Pharmacy, Mersin, Turkey
}

\begin{abstract}
Epilepsy is one of the most complicated neurological disorders associated with a brain disorder in which, after an initial physiological insult, the networks of neurons regroup and communicate abnormally that can be defined as the neuronal hypersynchronizayion. The affected part of brain defines the patient's abnormality behavior. Unlike the younger patients, who can become seizure free after the age of 16-18, older patients are hardly able to overcome the seizures, especially once the type of seizure developed to generalize tonic-clonic phase. Globally, epilepsy is considered as a disease which is originated from the disorder of electrical function of the brain and estimated to effect approximately 50 million people worldwide. Pharmacoresistance, drug interactions, drug tolerability and various adverse effects are among the common problems associated with the treatments of epilepsy with antiepileptic drugs (AEDs). Although, approximately $70 \%$ of the patients exhibit seizures that can be controlled with most AEDs, the remaining $30 \%$ of the patients fail to respond to treatment with AEDs. Thus, looking for alternatives such as traditional treatment methods like utilizing medicinal plants, ketogenic diet, and the Atkins diet as well as self-physical therapy like relaxation and yoga, are all positive options that can be considered as replacement and supportive therapy methods for the medications which are used in seizure control of epilepsy. Medicinal plants are more commonly used by folk for making infusions administered as herbal teas for the pain relief and maintaining good health. Investigating the active components of a plant extract, isolating and identifying their structure and pharmacological effects, and finally utilizing them as a new agent from nature with fewer side effects and high economic value is a widely interested topic in the field of ethnoparmacology. In addition to AEDs, which are currently used, the suggested alternative therapies are also able minimize the seizures of epilepsy but the surgical intervention still remains as the last option in the treatment of epilepsy.
\end{abstract}

Key Words: Epilepsy, antiepileptics, complementary and alternative therapies, drug interactions, surgical intervention

\section{Introduction}

Epilepsy is a term used to describe the electrohyperactivity disorder of the brain, which affects different areas of the brain and according to that termed as partial and general seizures. Moreover, different neurotransmitters have played major role in the initiation of seizures, and at the same time suppressing the development of chronic epileptic form. The best-known neurotransmitters involved in epilepsy are $\gamma$-aminobutyric acid (GABA), glutamate, serotonin, acetylcholine, Endocannabinoid (1-3). Epilepsy can affect people of all ages, all races, different socials and at any time. The prevalence of the disease showed to reach over 50 million, $75 \%$ of which live in scarce income countries with little or no access to medical services $(4,5)$. In Turkey few data have been obtained to estimate the prevalence of epilepsy throughout the country; however, statistical analysis estimated the prevalence of epilepsy in Turkey is 5.3/1.000 which is higher than developed countries. While the lowest prevalence has been reported to be in Japan at 1.5 per 1.000. Table 1 presents the prevalence of epilepsy in Turkey, while Table 2 presents the global prevalence of the seizure in the world according to the data obtained from World Health Organization (WHO) report (6-9). Major causes of the disease are genetic mutation, head injury, and hypoglycemia (10). Despite the fact that, there is no conclusive treatment for epilepsy, many medicinal drugs, and complementary therapies are utilized as alternative treatment to support the health state of the patients according to their ages, health situations, and state of pregnancy (11). However, antiepileptic drugs are neither preventive nor curative; they used to control symptoms of seizures and save the patient's life. Antiepileptic drugs are the first class of medications used among all alternative treatment; however, risk factors increase once drug intake increased, aging, drug resistance, tolerance and health state (12). Some AEDs are reported to be used not only in epilepsy 
Table 1. The prevalence of epilepsy in Turkey (rural and urban)

\begin{tabular}{lccc}
\hline The parameter & Rural & Urban & Total \\
\hline Total population surveyed & 6.680 & 4.817 & 11.497 \\
Suspected cases of epilepsy & 685 & 262 & 947 \\
Confirmed active cases of epilepsy & 59 & 22 & 81 \\
Prevalence ratio of epilepsy & $8.8 / 1000$ & $4.5 / 1000$ & $7.0 / 1000$ \\
\hline
\end{tabular}

Table 2. The globe prevalence of epilepsy

\begin{tabular}{lc}
\hline WHO statistic estimation of epilepsy prevalence & The rate of epilepsy prevalence \\
\hline Africa & 6178705 \\
America & 2094493 \\
East Mediterranean & 1814158 \\
Europe & 1588074 \\
South East Asia & 3494221 \\
Western Pacific & 2293467 \\
\hline
\end{tabular}

but also in certain diseases, like migraine attacks, neuropathic pain, bipolar disorder, anxiety, depression and many other disorders $(13,14)$. The mechanism of action of most AEDs are not specific; one drug may affect different target receptors with wide spectrum activity, which in turn can affect different conditions like seizures, relaxation, sedation, depression, and migraine. Thus, they contribute to variable effects depending on the condition being treated (15). Despite the fact that epilepsy is diagnosed with only two or more seizures provoke without an identifiable cause, misdiagnosis of epilepsy sometimes cannot be avoided. At the epilepsy clinics, investigations have concluded that about $20 \%$ to $30 \%$ of patients have been evaluated with misdiagnosis of epilepsy such as psychogenic, syncope, multiple sclerosis, rarely hypoglycemia, panic attacks, paroxysmal movement disorders, paroxysmal sleep disorders, transient ischemic attacks, and migraines, which were all misdiagnosis states of patients with epilepsy (16). In this review, medical drugs of anti-epileptics are classified according to their mechanism of action, generation; seizure types, patient state, age, and discussing the most commonly used alternative therapies for epilepsy.

According to their mechanism of action Epilepsy results from recurrent spontaneous electrical stimulate of the brain neurotransmitters, which could be in one part of the brain hemisphere or both parts. However, treating this electrical disorder cannot be controlled by monotherapy of AEDs in every time, as those electrical impulses can disrupt more than one part of brain hemispheres. Thus, polytherapy are more preferred in this cause for full seizure control. However, and as the mechanism of most AEDs cannot be specific, a drug with a different mechanism of action and broad spectrum is more preferable than the others, which can develop drug resistance due to the specific mechanism of it's action (13). In general, the mechanism of AEDs can affect the function of neurotransmitters, or neuron membrane ionic transportation mechanism, or can impair neuronal network formation (18). To understand the mechanism of action of most used anti-epilepsy drugs, we can scrutinize the following explanations.

\section{Voltage-gated sodium channels}

Voltage-gated channel, is a protein of multiple subunits, one Alpha basic activity subunit and one or more Beta subunit that alters the basic role of Alpha subunit. The distribution of the channels is different according to their Alpha subunit type in the central nervous system (CNS). In addition to Nav 1.1 and Nav 1.9, Nav 1.2 is predominant in the brain, any mutation in one of these channels leads to the expression of genetic epilepsies (19). Antiepileptic drugs have a high affinity for binding to these channels and as a result suppressing their action. Thus, they indirectly block the repetitive neuronal firing and its depolarization. Moreover, it modulates the release of the both inhibitory and excitatory neurotransmitter like glutamate without a direct effect on the synaptic response (20). The most common drugs used for this mechanism are phenytoin, which suggested to have a pro-convulsant effect, carbamazepine, oxcarbazepine (and its active 
metabolite licarbazepine) eslicarbazepine acetate, and modern drugs lamotrigine, felbamate, topiramate, zonisamide, rufinamide, and lacosamide. Which are used for focal and primary generalized tonic-clonic seizures $(21,22)$.

Voltage-gated calcium channel: Voltage-gated calcium channel is the channel that control neurotransmitter release at presynaptic nerve terminals. It is composed of protein subunits of a single alpha-subunit, in addition to beta- and alpha 2delta-subunits that alter the basic role of alphasubunit but not the channel functionality. Highvoltage-activated (HVA) channels respond to a high depolarizing action potential in both pre-synaptic neurotransmitter release and the postsynapse. While low-voltage activated (LVA) channel respond to the low depolarization action potential that gives rise to transient (T-type) currents in an intrinsic oscillatory activity, which underlines spike-and-wave discharges of generalized absence seizures $(20,22)$. However, the channels have been expressed by isoforms in thalamocortical circuits and encoded by separate genes denoted as Cav3.1, Cav3.2, and Cav3.3. Ethosuximide is reported to block all three-channel types, as it is the most effective drug used in controlling absence seizures in addition to zonisamide $(12,13,23)$. While the drugs that affect the mechanism of (HVA) channels are levetiracetam, lamotrigine, gabapentin, felbamate, topiramate, pregabalin as summarized in Table $3(12,24)$.

Voltage-gated potassium channels: Voltage-gated potassium channels are originally responsible for depolarization of the cell membrane of an action potential. It is a composite of alpha-subunits, which have the same structure of alpha-subunits of voltagegated sodium and calcium channels. However, they have been classified into 12 sub-families of voltagegated $\mathrm{K}+$ channels (Kv1 to $\mathrm{Kv12}$ ). $\mathrm{Kv1}$ to $\mathrm{Kv} 4$ channels were shown to be expressed in dendrites, axons and nerve terminals, while $\mathrm{Kv} 7$ channels were found in the cell soma and axon initial segment that is responsible for the M-current. Any mutations in these genes result in genetic epileptic states. It has been shown that confirmation in the KCNA1 gene, which encodes Kv1.1 subunit, results in episodic ataxia type 1, while mutations in KCNQ genes, which encode Kv7 channels, results in neonatal seizures (19). The most common AED used for this mechanism is ezogabine (25).

Inhibitory neurotransmission: The inhibitory neurotransmitter of GABA, which is synthesized from glutamate by a glutamic acid decarboxylase enzyme and released to act on both $G_{A B A}$ and $\mathrm{GABA}_{\mathrm{B}}$ receptors, has a big role in seizure overcome (22). There are two groups of the $\mathrm{GABA}$ receptor, $\mathrm{GABA}_{\mathrm{A}}$ group receptors, which are Cys loop-type ligand-gated chloride channels, represents a significant target for most antiepileptic drugs. And $\mathrm{GABA}_{\mathrm{B}}$ receptors are heterodimeric $G$-protein coupled receptors that have contrary functions of both activating potassium channels and inhibiting calcium channels of the pre-synaptic, and it is not a target

Table 3. AEDs used according to their mechanism of action

\begin{tabular}{ll} 
AEDs mechanism of action & \multicolumn{1}{c}{ AEDs } \\
\hline $\begin{array}{l}\text { Voltage-gated channels } \\
\text {-Voltage-gate sodium channel }\end{array}$ & $\begin{array}{l}\text { Phenytoin, fosphenytoin, carbamazepine, oxcarbazepine, } \\
\text { eslicarbazepine acetate, lamotrigine, lacosamide, topi ramate, } \\
\text { zonisamide, rufinamide } \\
\text { Ethosuximide }\end{array}$ \\
-Voltage-gate calcium channel & Ezogabine \\
-Voltage-gate potassium channel & \\
\hline GABA inhabitation & Phenobarbital, primidone, benzodiazepines (diazepam, \\
- GABA receptors & $\begin{array}{l}\text { lorazepam, clonazepam), topiramate, felbamate } \\
\text { Tiagabine }\end{array}$ \\
- CAT-1GABA transporter & Vigabatrin \\
-GABA transaminase & \\
\hline Synaptic release machinery & Levetiracetam \\
-SV $2 \mathrm{~A}$ & Gabapentin, gabapentin enacarbil, pregabalin \\
- $\alpha 2 \gamma$ & \\
\hline Inotropic glutamate receptors & Perampanel \\
-AMPA receptor & Valproate, felbamate, topiramate, zonisamide, rufinamide, \\
-Mixed/unknown & adrenocorticotropin \\
\end{tabular}

East J Med Volume:23, Number:1, January-March/2018 
for most AEDs (28). A neurotransmitter of GABA have been found to exist in four distinct cloning protein means of transport forms GAT-1, GAT-2, GAT-3, and BGT-1 that is presented for reuptake by glial cells and localized in nerve terminals. Thus, tiagabine found to be a potent inhibitor of GAT-1 in neurons and glia, and inhibit GABA reuptake and also compounds belonging to benzodiazepine groups, such as diazepam, lorazepam, and clonazepam; however, phenobarbital have shown to have the same mechanism of action $(29,30)$.

\section{GABA Transaminase: 4-Aminobutyrate} aminotransferase (GABA-transaminase) is an enzyme that stimulates the transformation of GABA and 2-oxoglutarate into succinic semialdehyde and glutamate, reported to inactivate the GABA neurotransmitters. Vigabatrin is an irreversible enzyme inhibitor acting by inhibiting the action of GABA transaminase and used as a pro-convulsant and anticonvulsant due to its effect resulting from the overflow of GABA into the extracellular space. Whereas tiagabine inhibit the sweep of GABA from the synaptic cleft by reducing GABA reuptake in addition to sodium valproate, gabapentin, and topiramate, which plays an important role in increasing neurotransmitter synthesis $(31,34)$.

\section{Synaptic release machinery}

$\mathbf{S V}_{2 \mathrm{~A}}$ : Secretory vesicles consist of $\mathrm{SV}_{2 \mathrm{~A}}$ glycoprotein membrane, which exist in neurons, endocrine cells and possibly immune cells. Thus, levetiracetam is a target for $\mathrm{SV}_{2 \mathrm{~A}}$ glycoprotein (34, 36), which reduce the synaptic release of the excitatory (glutamate) and inhibitory (GABA) neurotransmitters during high activation potential.

A2 $\delta$-1: A2 $\delta-1$ protein is an accessory subunit of voltage-gated calcium channels that are targets of both gabapentin and pregabalin $(31,32)$. Table 3 presents the mechanism of action of most used AEDs (24).

Glutamate receptors: Both perampanel and phenobarbital showed to have target effects on glutamate receptors. Perampanel is a noncompetitive $\quad \alpha$-amino-3-hydroxy-5methylisoxazole-4-propionic acid (AMPA) receptor inhibitor; however, it was reported to influence AMPA receptor by a conformational change of its subunits to impede their ability to ward glutamate translation. On the other hand, felbamate showed to be an antagonist for the Nmethyl-D-aspartate subtype glutamate receptor (NMDA), while topiramate for kainate receptors (20).
Carbonic anhydrase: Maintaining the local $\mathrm{pH}$ balance of the CNS is critically important for normal functional performance. They catalyze the reverse reaction of carbon dioxide and water to bicarbonate and hydrogen ions $\left(\mathrm{CO}_{2}+\mathrm{H}_{2} \mathrm{O} \leftrightarrow\right.$ $\left.\mathrm{HCO}_{3^{-}}+\mathrm{H}+\right)$. The forward reaction is rapid, whereas reverse reaction is modest. As a result, localized acidosis, increased bicarbonate ion concentration decrease NMDA receptor activity, and enhances inhibitory neurotransmission by promoting the responsiveness of $\mathrm{GABA}_{\mathrm{A}}$ receptors. Topiramate, acetazolamide zonisamide lacosamide are known to share this mechanism (22).

\section{According to their generation type}

Choosing the appropriate AEDs can some time be daunting for the physician, which usually stand on selecting the most efficient, tolerable, and safe drug. However, AEDs have been classified into various generations, as old or new classes. For years, only a limited number of AEDs were available, and many patients were forced to choose between a life of seizures or a life of intolerable drug side effects. Thus, researchers have kept looking for noval drug with less side effect, safe and well tolerable. They have come with the novel class of AEDs, such as topiramate, lamotrigine, levetiracetam that bear the characteristics of safety and tolerability than the former or old class of AEDs such as phenobarbitone, phenytoin, carbamazepine, valproate. Table 4 summarizes AEDs generations with old and novel or newer classes (34).

\section{According to the type of seizure}

Antiepileptic drugs are the first choice of treatment for people with epilepsy. Moreover, approximately $70 \%$ of patients have been shown to be completely controlled with AEDs. However, choosing the appropriate kind of AEDs to stand on the state of a patient like age, health, wellness, lifestyle, pregnancy, the type of seizure, and how frequently it sparks and the affected area of the brain from partial or general seizure. Narrowspectrum AEDs such as carbamazepine, benzodiazepines, eslicarbazepine acetate, ethosuximide, gabapentin, lacosamide, methsuximide, oxcarbazepine, perampanel, phenobarbital, phenytoin, pregabalin, rufinamide, tiagabine hydrochloride, vigabatrin, or broadspectrum such as clonazepam, clorazepate, ezogabine, felbamate, lamotrigine, levetiracetam, lorazepam, primidone, topiramate, valproic acid, and zonisamide are used according to above

East J Med Volume:23, Number:1, January-March/2018 
mentioned factors. Table 5 summarizes AEDs according to the seizure types (37).

\section{According to the state and the age of the patient}

Elderly patients: Elder people are usually more susceptible to complex partial seizures than those of younger ones are. However, they showed to have some specific conditions developed by aging such as a decrease in blood flow in the hepatic and renal organs, which causes an increase in drug half-life time and as a consequence decreased drug elimination. Furthermore, a decreased albumin level causes an increase in the free fraction of the administered drug leading to a toxic level of the drug. That is why caution must be taken by starting with a lower dose and then increasing it gradually (37).

In children: Epilepsy in children is twice as common when comparing them with adults; its prevalence is reported to be 700 per 100000 under at the age of 16 years old. However, children with epilepsy can be classified into two categories. The first category are those with idiopathic focal or generalized epilepsy, and who are more probably being influenced by AEDs. Moreover, their behavioral deterioration is unlikely to be serious. The second category are those whom epilepsies has not been identified (probably symptomatic) and less probably to be impacted by AEDs. Usually, the administered dose in children must be twice of the adult dose as they exhibit a short half-lifetime and faster elimination rate. Table 6 summarizes AEDs according to epilepsy syndromes (40). As a safe starting treatment for children, they usually start with monotherapy; however, the reason of failure of full seizure control with monotherapy treatment is the discontinuation of drug taken over a short period and substituting it with polytherapy drugs, which might be early for treatment, but late for a development of side effects and drug resistance. However, early switch to monotherapy treatment might improve controlling seizure in children and avoiding early resistance and side effects. In general, polytherapy of AEDs are used to treat myoclonic, absence epilepsy and are used after the failure of monotherapy control. Sleep disorder in epileptic children can increase seizure activity and may lead to hyperactivity behavior during the daytime. As a result, sleep control drugs might be beneficial in arranging sleep disorder (39). The most known drugs used in children are sodium valproate, which is used to treat generalized seizures and carbamazepine, which is used for focal seizures.

Table 4. AEDs according to their generation

\begin{tabular}{l|l}
\hline \multicolumn{2}{c}{ According to their generation type } \\
\hline The first generation & $\begin{array}{l}\text { Ethosuximide, phenytoin, phenobarbital, valproic acid, } \\
\text { carbamazepine }\end{array}$ \\
\hline The second generations & $\begin{array}{l}\text { Zonisamide, oxcarbaze, gabapentin, lamotrigine, } \\
\text { levetiracetam, felbamatepine, rufinamid, tiagabine, } \\
\text { pregabalintopiramate, vigabatrin, clobazam }\end{array}$ \\
\hline The third generation & Ezogabine, lacosamide, perampanel \\
\hline The older antiepileptic drugs & Phenobarbitone, phenytoin, carbamazepine, valproate \\
\hline Commonly used newer antiepileptic drugs & Topiramate, lamotrigine, levetiracetam \\
\hline
\end{tabular}

Table 5. AEDs according to seizure type

\begin{tabular}{l|l}
\hline $\begin{array}{l}\text { According to seizure type } \\
\text { (with or without secondary } \\
\text { generalization) }\end{array}$ & $\begin{array}{l}\text { Zonisamid, phenytoin, valproate, phenobarbital, gabapentin, } \\
\text { primidone, felbamate, lamotrigine, oxcarbazepine, } \\
\text { carbamazepine, vetiracetam, topiramate, tiagabine }\end{array}$ \\
\hline $\begin{array}{l}\text { Generalized seizures } \\
\text { Absence: }\end{array}$ & $\begin{array}{l}\text { Topiramate, valproate, lamotrigine, levetiracetam, } \\
\text { ethosuximide } \\
\text { Myoclonic: }\end{array}$ \\
$\begin{array}{l}\text { Zonic-clonic: } \\
\text { lamotrigine } \\
\text { Phenytoin, carbamazepine, zonisamide, felbamate, lamotrigine, } \\
\text { valproate, levetiracetam, topiramate }\end{array}$ \\
\hline
\end{tabular}

East J Med Volume:23, Number:1, January-March/2018 
Table 6. AEDs according to epilepsy syndrome

\begin{tabular}{|c|c|c|c|c|}
\hline Syndromes & First line drug & $\begin{array}{l}\text { Second line } \\
\text { drug }\end{array}$ & Other drugs & $\begin{array}{l}\text { Drugs to avoid } \\
\text { (increase the } \\
\text { seizure) }\end{array}$ \\
\hline Childhood absence epilepsy & $\begin{array}{l}\text { Ethosuximide, } \\
\text { lamotrigine, } \\
\text { valproate }\end{array}$ & $\begin{array}{l}\text { Levetiracetam, } \\
\text { topriamate }\end{array}$ & & $\begin{array}{l}\text { Carbamazepine } \\
\text { oxcarbazepine, } \\
\text { phenytoin, } \\
\text { tiagabine, } \\
\text { vigabatrin }\end{array}$ \\
\hline Juvenile absence epilepsy & $\begin{array}{l}\text { Lamotrigine, } \\
\text { valproate }\end{array}$ & $\begin{array}{l}\text { Levetiracetam, } \\
\text { topiramate }\end{array}$ & & $\begin{array}{l}\text { Carbamazepine, } \\
\text { oxcarbazepine, } \\
\text { phenytoin, } \\
\text { tiagabine, } \\
\text { vigabatrin }\end{array}$ \\
\hline Juvenile myoclonic epilepsy & $\begin{array}{l}\text { Lamotrigine, } \\
\text { valproate }\end{array}$ & $\begin{array}{l}\text { Clobazam, } \\
\text { clonazepam, } \\
\text { levetiracetam, } \\
\text { topiramate }\end{array}$ & Acetazolamide & $\begin{array}{l}\text { Carbamazepine, } \\
\text { oxcarbazepine, } \\
\text { phenytoin, } \\
\text { tiagabine, } \\
\text { vigabatrin }\end{array}$ \\
\hline $\begin{array}{l}\text { Epilepsy with generalized } \\
\text { tonic-clonic seizure }\end{array}$ & $\begin{array}{l}\text { Carbamazepine, } \\
\text { lamotrigine, } \\
\text { topiramate, } \\
\text { valproate }\end{array}$ & Levetiracetam & $\begin{array}{l}\text { Acetazolamide, } \\
\text { clobaza, } \\
\text { clonazepam, } \\
\text { oxcarbazepine, } \\
\text { phenobarbital, } \\
\text { phenytoin, } \\
\text { primidone }\end{array}$ & $\begin{array}{l}\text { Tiagabine, } \\
\text { vigabatrin }\end{array}$ \\
\hline $\begin{array}{l}\text { Focal epilepsy crytogenic or } \\
\text { symotomatic }\end{array}$ & $\begin{array}{l}\text { Carbamazepine, } \\
\text { lamotrigine, } \\
\text { oxcarbazepine, } \\
\text { valproate, } \\
\text { topiramate }\end{array}$ & $\begin{array}{l}\text { Clobazam, } \\
\text { gabapentine, } \\
\text { levetiracetam, } \\
\text { phenytoin, } \\
\text { tiagabine }\end{array}$ & $\begin{array}{l}\text { Acetazolamide, } \\
\text { clonazepam, } \\
\text { phenobarbital, } \\
\text { primidone }\end{array}$ & \\
\hline Infantile spasms & $\begin{array}{l}\text { Hormone } \\
\text { therapy* } \\
\text { vigabatrin }\end{array}$ & $\begin{array}{l}\text { Clobazam, } \\
\text { gabapentine, } \\
\text { valproate, } \\
\text { topiramate }\end{array}$ & Nitrazepam & $\begin{array}{l}\text { Carbamazepine, } \\
\text { oxcarbazepine }\end{array}$ \\
\hline $\begin{array}{l}\text { Bening epilepsy with } \\
\text { centrotemporal spikes }\end{array}$ & $\begin{array}{l}\text { Carbamazepine, } \\
\text { lamotrigine, } \\
\text { oxcarbazepine, } \\
\text { valproate }\end{array}$ & $\begin{array}{l}\text { Levetiracetam, } \\
\text { topiramate }\end{array}$ & Sulthiame & \\
\hline $\begin{array}{l}\text { Bening epilepsy with } \\
\text { occipital paroxysms }\end{array}$ & $\begin{array}{l}\text { Carbamazepine, } \\
\text { lamotrigine, } \\
\text { oxcarbazepine, } \\
\text { valproate }\end{array}$ & $\begin{array}{l}\text { Levetiracetam, } \\
\text { topiramate }\end{array}$ & & \\
\hline $\begin{array}{l}\text { Dravet syndrome } \\
\text { (severe mycoclonic epilepsy } \\
\text { of infancy) }\end{array}$ & $\begin{array}{l}\text { Carbamazepine, } \\
\text { valproate, } \\
\text { topiramate, } \\
\text { clobazam }\end{array}$ & $\begin{array}{l}\text { Levetiracetam, } \\
\text { stiripentol }\end{array}$ & Phenobarbital & $\begin{array}{l}\text { Carbamazepine } \\
\text { lamotrigine, } \\
\text { oxcarbazepine, } \\
\text { vigabatrin }\end{array}$ \\
\hline
\end{tabular}

Hormone therapy:*eg, corticosteroids (or adrenocorticotrophic hormone, ghrelin, leptin)

East J Med Volume:23, Number:1, January-March/2018 
Table 7. AEDs interaction with other drugs during co-administration.

\begin{tabular}{ll}
\hline ADEs & Interfere drugs \\
\hline Benzodiazepines & $\begin{array}{l}\text { Clobazam, clonazepam, alprazolam, desmethyldiazepam, midazolam, } \\
\text { diazepam }\end{array}$ \\
\hline Cardiovascular drugs & $\begin{array}{l}\text { Amiodarone, alprenolol, atorvastatin, digoxin, disopyramide, felodipine, } \\
\text { metoprolol, dicoumarol, mexiletine, nimodipine, nifedipin, propranolol, } \\
\text { nisoldipine, quinidine, simvastatin, warfarin, verapamil }\end{array}$ \\
\hline Antidepressants & $\begin{array}{l}\text { Bupropion, amitriptyline, citalopram, doxepin, clomipramine, mianserin, } \\
\text { desmethyl clomipramine, desipramine, imipramine, nortriptyline, } \\
\text { protriptyline, mirtazepine, nefazodone, paroxetine }\end{array}$ \\
\hline Antimicrobials & $\begin{array}{l}\text { Doxycycline, albendazole, indinavir, griseofulvin, itraconazole, praziquantel, } \\
\text { metronidazole }\end{array}$ \\
\hline Antineoplastic drugs & $\begin{array}{l}\text { Busulfan, 9-aminocampthotecin, cyclophosphamide, irinotecan, } \\
\text { methotrexate, nitrosoureas, etoposide, vinca alkaloids, tamoxifen, } \\
\text { procarbazine, teniposide, paclitaxel, thiotepa, topotecan, ifosfamide }\end{array}$ \\
\hline Immunosuppressants & $\begin{array}{l}\text { Cyclosporin, tacrolimus, sirolimus } \\
\text { Miscellaneous }\end{array}$ \\
\hline thyroxine, theophylline, vecuronium \\
\hline Steroids & $\begin{array}{l}\text { Dexamethasone, cortisol, methylprednisolone, hydrocortisone, } \\
\text { contraceptives, prednisolone, prednisone }\end{array}$ \\
\hline
\end{tabular}

The combination of AEDs with hypnotic-sedative effect ought to be avoided, and at least one broadspectrum of AEDs should be used in children with multiple seizure types. Combination drug therapy like ethosuximide and valproate used for absence seizures, and lamotrigine and valproate are used for absence and myoclonic seizures. Shudder attacks, staring spells, breath-holding spells, are conditions of misdiagnosed epilepsy in children. Thus, electroencephalogram (EEG) and Magnetic resonance imaging (MRI) are useful diagnosis devices in asserting the tolerance of applicator treatment regime or elucidate the misdiagnosis conditions and is useful in deciding on treatment change or starting with alternative treatment like surgery, or interventional hormone treatments, such as immunoglobulins, or traditional homeopathy or food control like ketogenic diet. On the other side, seizures in the neonate are considered as a significant sign of the high rate of mortality and neuron morbidity than those of adult individuals due to less degree of myelin development. Seizure in neonates can be clonic, myoclonic, and atonic. The first line of neonate treatment is phenobarbital, while phenytoin and benzodiazepines remain as alternatives. Persistent seizures may require the use of a parenteral (i.v.) benzodiazepine, such as lorazepam or midazolam $(37,39,40)$. However, hormone therapy has also been recorded in a neonatal seizure like corticoids.

Pregnant women: Taking antiepileptic drugs may conflict the chance for the women of being pregnant and for the male by reducing libido and impair the normal sexual activity. Carbamazepine, oxcarbazepine, valproate, and primidone are the most common drug used in epileptic pregnant women. While taking antiepileptic drugs by single (unmarried) women, tends to reduce concentrations of circulating steroidal hormones for pregnancy tendency. However, with pregnancy progression body physiological changes develop. Thus, the effect of drug absorption decreases with increase in the extracellular fluid volume. While plasma-unbound drug concentrations decrease as plasma protein concentrations increase glomerular filtration has also played important role in drug absorption, for example, increasing glomerular filtration during pregnancy progression, increase drug excretion process. In liver, the metabolic enzymes increase by increasing steroidal sex hormone concentrations during the pregnancy, which in turn decrease the drug concentration and accelerate its clearance by hepatic metabolic enzymes (41-49).

\section{Drug interactions}

Drug interactions have shown to increase or decrease the efficiency of AEDs from polytherapy of the AEDs themselves or even compensation of other medical drugs intake by the epileptic patients. The ADEs, phenobarbital, carbamazepine, primidone, and phenytoin have been reported to decrease the serum concentration of tiagabine, valproic acid, lamotrigine, ethosuximide, topiramate,

East J Med Volume:23, Number:1, January-March/2018 
zonisamide, felbamate, oxcarbazepine and benzodiazepine groups. While nitration of metabolized lamotrigine with phenobarbital by valproic acid has been shown to increase the serum concentration of lamotrigine by inhibition of its metabolism. Taking valproic acid with phenobarbital was reported to cause an elevation in serum concentration of phenobarbital due to secondary inhibition of metabolic enzyme CYP2C9 and CYP2C19 (50). On the other hand, oxcarbazepine and topiramate was shown to increase the serum concentration of phenytoin by the metabolic inhibition reaction. Phenobarbital, primidone, phenytoin, and carbamazepine, reported to decrease the serum concentration of other drugs taken by the patient. Table 7 drug interactions among ADEs are listed in $(51,52)$.

\section{Alternative treatment of epilepsy}

An alternative treatment is an ultimate choice after failing of chemical drugs in controlling seizures and in maintaining the safe health state of the patient or prophylaxis of seizure development (51). Recently, new test technique of therapeutic drug monitoring (TDM) is used for the successful choice of AEDs regime, which consider the patient's health state and age. While measuring the drug concentration in serum blood is useful in standing the clinical effectiveness, avoiding adverse drug reactions between ADEs themselves in polytreatment regime, prevention of seizure development, and minimization of adverse effect like endocrine system unbalance, cognition or even mood modification are important (52). Despite all those new techniques, they were not able to prevent the failure of some or even restricted toward selecting the most appropriate AEDs. Thus, many investigators and researchers have come out with different alternative paths to overcome the disadvantages of AEDs or to limit seizure progression. Supplements like pyridoxine (Vit B6), ascorbic acid (Vit C) and antioxidant, compounds like $\alpha$-tocopherol, polyphenolics, flavonoids that found to be present in different herbal plants like Curcum and Epilobium species, ginsenosides and terpenoid saponins in Panax ginseng, propolis in Honeybee that contains caffeic acid phenethyl ester, Ginkgo biloba leaves that is rich in flavonoids and terpenes (27). Plants like Brassica nigra, Ferula assa foetida gum, Nigella sativa, Melissa officinalis, are among discovered plants used in seizure control $(50,51,54,55)$. Studies have proved that more than 50 references, studied the plant in vivo/in vitro in testing seizure controlling (53). Table 8 indicates the most used plants in epilepsy control (54). Using ketogenic diet was developed in 1920 which stringent with lowprotein, low-carbohydrate diet, and a high-fat consumption. However, constipation, calorie intake, the stone formation of kidney, ketosisacidosis, growth retardation, anemia, and weight loss were disadvantages of the ketogenic diet, which restricted it's use compared with Atkins diet (57). Thus, Atkins diet has emerged to overcome the disadvantage of the ketogenic diet, which based on restriction of carbs (carbohydrates) while encouraging intake of protein, fats, with less index of blood glucose, which considered being easier than ketogenic diet and with less side effects (58). Homeopathy therapy, which formed on two master principles, the dynamization principle that comes from nature and prepared by a serial process of dilution and vigorous shaking time dependence. In dynamization, high-potency remedies based on (ultra-high dilutions of $\mathrm{C} 12$ and above) transition of the bioenergy of substances that diluted with single molecule continent from the original one to the diluted solvent. Thus, the minimal dose of a different compound, which at a higher dose causing the same biologic disturbance effect, is used for a proposed cure (heterogeneous). The second principle is homeopathic remedies like silicea, cuprum, causticum, hyoscyamus, aethusa cynapium, agaricus muscarius, artemisia absinthium, stramonium, and cicuta virosa are also used in controlling seizures. Chiropractic is a natural therapy, used in pediatric patients to promoted neurotransmitter release or activate the receptors found in the spine, which cause a modification in neuronal afferent. (51). Relaxation and Yoga were also reported in modulating limbic seizure via the hypothalamus and endocrine release balance as it was recorded to decrease $62 \%$ seizure in 3 months and $86 \%$ in the later 6 months. However, grapefruit and pyrrolizidine, which are taken as herbal teas, and squeezed juice; coffee drinks and cachalot consumption, showed to cause a serious interaction with AEDs. All those theories miss definite clear indexing toward seizure control form natural sources $(59,60)$.

\section{Surgical intervention treatment}

Surgical intervention is performed in patients with seizures that cannot be controlled by medications or alternative treatments. However, different surgical methods are used to capture the affected area of the brain either by removing the affected area or by an insulting simulative device that helps 
Table 8. The most used plants in epilepsy.

\begin{tabular}{|c|c|c|c|}
\hline Plant & Part used & Plant & Part used \\
\hline $\begin{array}{l}\text { Epilobium birsutum } \\
\text { (Onagraceae) }\end{array}$ & Aerial parts & $\begin{array}{l}\text { Bosciaalbitrunca } \\
\text { (Capparaceae) }\end{array}$ & Roots, leaves \\
\hline $\begin{array}{l}\text { Brassica nigra } \\
\text { (Brassicaceae) }\end{array}$ & Seed & $\begin{array}{l}\text { Capparistomentosa } \\
\text { Lam. (Capparaceae) }\end{array}$ & Roots \\
\hline $\begin{array}{l}\text { Cyperus rotundas } \\
\text { (Cyperaceae) }\end{array}$ & Roots, rhizomes & $\begin{array}{l}\text { Commelina Africana } \\
\text { Linn. (Commelinaceae) }\end{array}$ & Leaves, roots \\
\hline $\begin{array}{l}\text { Ferula AssaFoetida } \\
\text { (Apiaceae) }\end{array}$ & Gum & $\begin{array}{l}\text { Maytenussenegalensis (Lam.) } \\
\text { Celastraceae }\end{array}$ & Leaves, twigs \\
\hline Ginkgo biloba & Leaves & $\begin{array}{l}\text { Crassula alba Forssk. } \\
\text { (Crassulaceae) }\end{array}$ & Fruits, stem, roots \\
\hline Marijuana (disambiguation) & Leaves, flowers & $\begin{array}{l}\text { Eucleadivinorum } \text { Hiern } \\
\text { (Ebenaceae) }\end{array}$ & Fruits, roots \\
\hline $\begin{array}{l}\text { Curcuma longa } \\
\text { (Zingiberaceae) }\end{array}$ & Rhizome & $\begin{array}{l}\text { Cucumishirsutus } \\
\text { Sond. (Cucurbitaceae) }\end{array}$ & Bark, roots, leaves \\
\hline $\begin{array}{l}\text { Lavandula angustifolia } \\
\text { (Lamiaceae) }\end{array}$ & Flowers, steam & $\begin{array}{l}\text { Croton gratissimus } \\
\text { Burch. (Euphorbiaceae) }\end{array}$ & $\begin{array}{l}\text { Roots, seeds, } \\
\text { leaves }\end{array}$ \\
\hline $\begin{array}{l}\text { Melissa officinalis } \\
\text { (Lemon Balm) }\end{array}$ & Leaves, whole plant & $\begin{array}{l}\text { Jatropha curcas } \\
\text { Linn. (Euphorbiaceae) }\end{array}$ & Bark, leaves, gum \\
\hline Casimiroaedulis (Rutaceae) & Leaves & $\begin{array}{l}\text { Acacia karroo Hayne } \\
\text { (Fabaceae) }\end{array}$ & Roots, leaves \\
\hline Vitexagnuscastus & Fruit, leaves & $\begin{array}{l}\text { Abrusprecatorius Linn. } \\
\text { (Fabaceae) }\end{array}$ & Whole plant \\
\hline Viscumcapense (Loranthaceae) & Stem & $\begin{array}{l}\text { Mimosa pudica Linn. } \\
\text { (Fabaceae) }\end{array}$ & Leaves, stem \\
\hline Cestrum nocturnum (Solanaceae) & Leaves & $\begin{array}{l}\text { Nuxia floribunda Benth. } \\
\text { (Loganiaceae) }\end{array}$ & $\begin{array}{l}\text { Roots, leaves, } \\
\text { berries }\end{array}$ \\
\hline $\begin{array}{l}\text { Calliandraportoricensis } \\
\text { (Mimosaceae) }\end{array}$ & Root, stem & $\begin{array}{l}\text { Phytolaccadodecandra } \\
\text { L'Herit. (Phytolaccaceae) }\end{array}$ & Leaves, root \\
\hline Pimpinellaanisum (Umbel) & $\begin{array}{l}\text { Essential oil from } \\
\text { fruits }\end{array}$ & $\begin{array}{l}\text { Meliaazedarach Linn. } \\
\text { (Meliaceae) }\end{array}$ & Roots, leaves \\
\hline $\begin{array}{l}\text { Nigella sativa (Ranunculaceae) } \\
\text { liferae) }\end{array}$ & Seed extract & $\begin{array}{l}\text { Oxygonumdregeanum } \\
\text { Meisn. (Polygonaceae) }\end{array}$ & $\begin{array}{l}\text { Leaves, fruits, } \\
\text { roots }\end{array}$ \\
\hline Casimiroaedulis (Rutaceae) & Leaves & $\begin{array}{l}\text { Catunaregam } \\
\text { spinosa (Thunb.) (Rubiaceae) }\end{array}$ & Leaves, roots \\
\hline Acorus calamus (Araceae) & Rhizome & $\begin{array}{l}\text { RubuspinnatusWilld. } \\
\text { (Rosaceae) }\end{array}$ & $\begin{array}{l}\text { Leaves, twigs, } \\
\text { fruits, roots }\end{array}$ \\
\hline Lannea discolor (Anacardiaceae) & Roots, leaves, stem & $\begin{array}{l}\text { Gardenia ternifoliaSchumach. } \\
\text { And Thonn (Rubiaceae) }\end{array}$ & $\begin{array}{l}\text { Roots, leaves, } \\
\text { fruits }\end{array}$ \\
\hline Hibiscus rosasinensis (Malvaceae) & Fresh flowers & $\begin{array}{l}\text { Clausenaanisata (Willd.) Hook. } \\
\text { F. ex Benth. (Rutaceae) }\end{array}$ & Ruits, roots \\
\hline Rauvolfia caffra (Apocynaceae) & $\begin{array}{l}\text { Leaves, stem, bark, } \\
\text { root }\end{array}$ & $\begin{array}{l}\text { Englerophytummagalismontanum } \\
\text { Krause (Sapotaceae) }\end{array}$ & $\begin{array}{l}\text { Leaves, fruits, } \\
\text { aerial parts }\end{array}$ \\
\hline
\end{tabular}

East J Med Volume:23, Number:1, January-March/2018 
Allahverdiyev et al / New therapeutic approaches in epilepsy

Table 9. The variety of surgical neurostimulation

\begin{tabular}{|c|c|c|c|c|}
\hline RNS & $\begin{array}{l}\text { Closed loop } \\
\text { Responsive } \\
\text { stimulation } \\
\text { Intracranial }\end{array}$ & $\begin{array}{l}\text { Infection } \\
\text { Intracranial } \\
\text { hemorrhage }\end{array}$ & $\begin{array}{l}\text { Seizure reduction at } 1 \text { year } \\
44 \% \text { and at } 2 \text { years } 53 \%\end{array}$ & $\begin{array}{l}\text { At } 1 \text { year } 44 \% \\
\text { At } 2 \text { years } 55 \%\end{array}$ \\
\hline DBS & $\begin{array}{l}\text { Open loop } \\
\text { Preprogrammed } \\
\text { Intracranial }\end{array}$ & $\begin{array}{l}\text { Infection } \\
\text { Intracranial } \\
\text { hemorrhage }\end{array}$ & $\begin{array}{l}\text { Seizure reduction from baseline at } \\
1 \text { year } 41 \% \text { and at } 5 \text { years } 69 \%\end{array}$ & $\begin{array}{l}\text { At } 1 \text { year } 43 \% \\
\text { At } 5 \text { years } 68 \%\end{array}$ \\
\hline VNS & $\begin{array}{l}\text { Open loop } \\
\text { Preprogrammed } \\
\text { Extracranial }\end{array}$ & $\begin{array}{l}\text { Local infection } \\
\text { Hoarseness } \\
\text { Vocal cord paralysis }\end{array}$ & $\begin{array}{l}\text { Seizure reduction at } 1 \text { year } \\
26.21 \% \text { and at } 5 \text { years } 55.8 \%\end{array}$ & $\begin{array}{l}\text { At } 1 \text { year } 44.5 \% \\
\text { At } 5 \text { years } 64.4 \%\end{array}$ \\
\hline
\end{tabular}

RNS: Responsive neurostimulation; DBS: Deep brain stimulation; VNS: Vagal nerve stimulation

neurotransmitter regulation and limit the seizure spread to adhesive areas. Thus, temporal lobectomy, cortical excision, hemispherectomy, corpus callosotomy, multiple subpial transactions, in addition to vagus nerve stimulator, which have been the oldest operation used since 1997, responsive nerve stimulation, deep brain stimulation, which have been used in Europe since 2010 but not in the USA, afterwards approved by Food and Drug Administration (FDA) in 2013. Those are different types of brain surgical interventions that are used according to seizure type and its location in the brain hemisphere; however, they are identified by EEG monitoring, magnetic resonance imaging, positron emission tomography, single-photon emission computed tomography, neuropsychological testing, functional MRI, and electrical brain mapping (62, 63). The difference between each device is the way of insertion. However, the target proposed of neurostimulation treatment is to decrease seizure frequency, prevent the development of secondary generalization and minimize many risk factors associated with intractable epilepsy. Table 9 summarizes the variety of surgical neurostimulations (64).

In the conclusion, in this review, we have summarized the most common treatments such as medicinal and herbal drugs, complementary alternatives, physical methods like relaxation, and yoga, used for epilepsy. Moreover, the drugs classified according to their generations, type of seizures, condition, and ages of the patient. Despite all those alternative treatment methods used for epileptic patients, it is dramatically important for the physician to select the most appropriate drug or path concerning health state and age of the patient, as well as the pregnancy state of the women. Besides these factors, the physician also should perform the most suitable treatment regime after determining the earlier diagnosis stages to minimize the common known consequences of drug side effects and drug resistance. Thus, the promotion of monotherapy drug is more advisable to be used in the treatment of epilepsy than polytherapy for reaching a successful seizure control with the longest period of using the same drug, which is sometimes supported by a known alternative, complementary treatment. Nevertheless, this does not convince all, some patients develop drug resistance, which limits the effectiveness of the monotherapy regime and requiring the switch to polytherapy treatment method to reach a full seizure control. However, resistance, interaction and high side effects of the drugs and other unplanned results with polytherapy treatment are the last choices to resort for surgical intervention. However, surgical interventions are not suitable for every individual which require high financial support in addition to qualified doctors. All of the available treatments used for epilepsy, there is still no any defined, decisive solution for the nightmare of epilepsy.

\section{References}

1. Werner FM, Coveñas R. Classical neurotransmitters and neuropeptides involved in generalized epilepsy: a focus on antiepileptic drugs. Curr Med Chem 2011; 18: 4933-4948.

2. Devinsky O, Cilio MR, Cross $\mathrm{H}$, et al. Cannabidiol: pharmacology and potential therapeutic role in epilepsy and other neuropsychiatric disorders. Epilepsia 2014; 556: 791-802.

3. Büget $\mathrm{B}$, Zengin A, Allahverdiyev $\mathrm{O}$, Enginar $\mathrm{N}$. Antimuscarinic-induced convulsions in fasted animals after food intake: evaluation of the effects of levetiracetam, topiramate and different doses of atropine. Naunyn-Schmiedeberg's Arch Pharmacol 2016; 389: 57-62.

4. Neligan A, Bell GS, Johnson AL, Goodridge DM, Shorvon SD, Sander JW. The long-term risk of

East J Med Volume:23, Number:1, January-March/2018 
premature mortality in people with epilepsy. Brain 2011; 134: 388-395.

5. World Health Organization. Epilepsy Factsheet No 999. World Health Organization 2012.

6. Huseyinoglu N, Ozben S, Arhan E, Palanci Y, Gunes N. Prevalence and Risk Factors of Epilepsy. Among School Children in Eastern Turkey. Pediatric Neurology 2012; 47: 13-18.

7. VeliogluS, Bakirdemir M, Can G, Topbas M. Prevalence of epilepsy in northeast Turkey. Epileptic Disord 2010; 12: 22-37.

8. Aziz H, Guvener A, Akhtar S, Hasan K. Comparative Epidemiology of Epilepsy in Pakistan and Turkey: Population-B ased Studies Using Identical Protocols. Epilepsia 1997; 38: 716-722.

9. Amudhan S, Gururaj G, Satishchandra P. Epilepsy in India I: Epidemiology and public health. Ann Indian AcadNeurol 2015; 18: 263 277.

10. Martins B, GrabnarI, Vovk T. "The role of reactive species in epileptogenesis and influence of antiepileptic drug therapy on oxidative stress. Current Neuropharmacology 2012; 10: 328-343.

11. Ricotti V, Delanty N. Use of Complementary and Alternative Medicine in Epilepsy. Current Neurology and Neuroscience Reports 2006; 6: 347-353.

12. Lasoñ W, Chlebicka M, Rejdak K. Research advances in basic mechanisms of seizures and antiepileptic drug action. Pharmacological Reports 2013; 65: 787-801.

13. Perucca E. An introduction to antiepileptic drugs. Epilepsia 2005; 46: 31-37.

14. Moavero R, Santarone M, Galasso C, Curatolo P. Cognitive and behavioral effects of new antiepileptic drugs in pediatric epilepsy. Brain Dev 2017; 39: 464-469.

15. René H. Levy, Lippincott Williams \& Wilkins. Antiepileptic Drugs. Fifth Edition 2002; 2-26.

16. Oliva M, Berkovic SF, Petrou S. Sodium channels and the neurobiology of epilepsy. Epilepsia 2012; 53: 1849-1859.

17. Faingold C, Browning R. Mechanisms of anticonvulsant drug action. Eur J Pediatr 1987; 146: 8-14.

18. Elgera C, Johnstonb S, Hoppea C. Diagnosing and treating depression in epilepsy. Science Direct 2016; 44: 184-193

19. Stafstrom CE. Persistent sodium current and its role in epilepsy. Epilepsy Curr 2007; 7: 15-22.

20. Coulter DA, Huguenard JR, Prince DA. Characterization of ethosuximide reduction of low-threshold calcium current in thalamic relay neurons. Ann Neurol 1989; 25: 582-593.

21. Graeme J S. Mechanisms of action of antiepileptic drugs. Chapter 25. University of Liverpool 2011.
22. Broicher T, Seidenbecher T, Meuth P, et al. Tcurrent related effects of antiepileptic drugs and a $\mathrm{Ca} 2+$ channel antagonist on thalamic relay and local circuit interneurons in a rat model of absence epilepsy. Neuropharmacology 2007; 53: 431-446.

23. Michael A. Rogawski and José Enrique Cavazos. Mechanisms of action of antiepileptic drugs. Chapter 43.2014.

24. Gu N, Vervaeke K, Hu H, et al. Kv7/KCNQ/M and $\mathrm{HCN} / \mathrm{h}$, but not $\mathrm{KCa} 2 / \mathrm{SK}$ channels, contribute to the somatic medium afterhyperpolarization and excitability control in CA1 hippocampal pyramidal cells. J Physiol 2005; 566: 689-715.

25. Wuttke TV, Seebohm G, Bail S, et al. The new anticonvulsant retigabine favors voltagedependent opening of the Kv7.2 (KCNQ2) channel by binding to its activation gate. MolPharmacol 2005; 67: 1009-1017.

26. Kwon YS, Park DH, Shin EJ, et al. Antioxidant Propolis attenuates kainate-induced neurotoxicity via adenosine A1 receptor modulation in the rat. Neurosci 2004; 355: 231-235.

27. Sahara S, Yanagawa Y, O'Leary DD, et al. The fraction of cortical GABAergic neurons is constant from near the start of cortical neurogenesis to adulthood. J Neurosci 2012; 32: 4755-4761.

28. Rho JM, Donevan SD, Rogawski MA. Direct activation of GABAA receptors by barbiturates in cultured rat hippocampal neurons. J Physiol 1996; 497: 509-522

29. Sohal VS, Keist R, Rudolph U, et al. Dynamic GABAA receptor subtype-specific modulation of the synchrony and duration of thalamic oscillations. J Neurosci 2003; 23: 3649-3657.

30. Overstreet LS, Westbrook GL. Paradoxical reduction of synaptic inhibition by vigabatrin. J Neurophysiol 2001; 86: 596-603.

31. Wu Y, Wang W, Richerson GB. Vigabatrin induces tonic inhibition via GABA transporter reversal without increasing vesicular GABA release. J Neurophysiol 2003; 89: 2021-2034.

32. Rho JM, Donevan SD, Rogawski MA. Direct activation of GABAA receptors by barbiturates in cultured rat hippocampal neurons. J Physiol 1996; 497: 509-522.

33. Schousboe A, Madsen KK, Barker-Haliski ML, et al. The GABA synapse as a target for antiepileptic drugs: a historical overview focused on GABA transporters. Neurochem Res 2014; 34: 1980 1987.

34. Dolphin AC. The $\alpha 2 \delta$ subunits of voltage-gated calcium channels. BiochimBiophysActa 2013; 1828: 1541-1549.

35. Stahl SM, Porreca F, Taylor CP, et al. The diverse therapeutic actions of pregabalin: is a single mechanism responsible for several 
pharmacological activities? Trends PharmacolSci 2013; 34: 332-339.

36. Bromfield EB, Cavazos JE, SirvenJI. An Introduction to Epilepsy. West Hartford (CT): American Epilepsy Society. 2006.

37. Brodie MJ, Tolerability and Safety of Commonly Used Antiepileptic Drugs in Adolescents and Adults: A Clinician's Overview. CNS Drugs 2017; 31: 135-147.

38. Schmidt D. Drug treatment strategies for epilepsy revisited: starting early or late? One drug or several drugs. Epileptic Disord 2016; 18: 356-366.

39. Raspall-Chaure M, Neville BG, Scott RC. The medical management of the epilepsies in children: conceptual and practical considerations. Lancet Neurol 2008; 7: 57-69.

40. Crawford P, Chadwick D, Cleland P, et al. The lack of effect of sodium valproate on the pharmacokinetics of oral contraceptive steroids. Contraception 1986; 33: 23-29.

41. Ashwal S. Postneural migration defects. In: Swaimann KF, Ashwal S (eds). Pediatric Neurology. Principles and Practice (3rded). St. Louis: Mosby 1999; 268-275.

42. Li G, Nowak M, Bauer S, et al. Levetiracetam but not valproate inhibits function of $\mathrm{CD} 8+\mathrm{T}$ lymphocytes. Seizure 2013; 22: 462-466.

43. Bartoli A, Gatti G, Cipolla G, et al. A doubleblind, placebo-controlled study on the effect of vigabatrin on in vivo parameters of hepatic microsomal enzyme induction and on the kinetics of steroid oral contraceptives in healthy female volunteers. Epilepsia 1997; 38: 702-707.

44. Artama M, Isojärvi JI, Auvinen A. Antiepileptic drug use and birth rate in patients with epilepsy a population-based cohort study in Finland. Hum Reprod 2006; 21: 2290-2295.

45. Bilo L, Meo R, Valentino R, Di Carlo C, Striano $S$, Nappi C. Characterization of reproductive endocrine disorders in women with epilepsy. J ClinEndocrinolMetab 2001; 86: 2950-2956.

46. Cawello W, Rosenkranz B, Schmid B, Wierich W. Pharmacodynamic and pharmacokinetic evaluation of coadministration of lacosamide and an oral contraceptive (levonorgestrel plus ethinylestradiol) in healthy female volunteers. Epilepsy 2013; 54: 530-536.

47. Coulam CB, Annegers JF. Do anticonvulsants reduce the efficacy of oral contraceptives.Epilepsia 1979; 20: 519-525.

48. Crawford PM. Managing epilepsy in women of childbearing age. Drug Saf 2009; 32: 293-307.

49. Perucca E. Clinically relevant drug interactions with antiepileptic drugs. British Journal of Clinical Pharmacology 2005; 1365-2125.
50. Bialer M, Doose DR, Murthy B, et al. Pharmacokinetic interactions of topiramate. ClinPharmacokinet 2004; 12: 763-780.

51. Allahverdiyev O, Dzhafar SS, Berköz M, Yıldırım M. The Commonly Used Therapy For Epilepsy.3rd International Convention of Pharmaceuticals and Pharmacies 2017; 739-741.

52. Nsour W, Lau C, Wong I. Review on phytotherapy in epilepsy. Seizure 2000; 9: 96-107.

53. Shashi P, Jangra M, Yadav A. Herbal and synthetic approaches for the treatment of epilepsy 2017; 4: 43-52.

54. Drugs R D. An Updated Overview on Therapeutic Drug Monitoring of Recent Antiepileptic Drugs. Drugs R D 2016; 303-316.

55. Kiasalari Z, Khalilia M, Roghania M, Sadeghiana A. Antiepileptic and Antioxidant Effect of Brassica nigra on Pentylenetetrazol-Induced Kindling in Mice. Iranian Journal of Pharmaceutical Research 2012; 11: 1209-1217.

56. Kiasalari Z, Khalili M, Roghani M, Heidari H, Azizi Y. Antiepileptic and Antioxidant Effect of Hydroalcoholic Extract of Ferula AssaFoetida Gum on Pentylentetrazoleinduced Kindling in Male Mice. Basic ClinNeurosci 2013; 4: 299-306.

57. Hariry RE. Anticonvulsant effects of hydroalcoholic extract of Melissa officinalis on pentylenetetrazole (PTZ) model of convulsion in mice. Journal of Medicinal Plants Research 2011; 5: 3803-3809.

58. Ilhan A, Gurel A, Armutcu F, Kamisli S, Iraz M. Antiepileptogenic and antioxidant effects of Nigella sativa oil against pentylenetetrazolinduced kindling in mice. Neuropharmacology 2005; 49: 456-464.

59. Tyagi A, Delanty N: Herbal remedies, dietary supplements, and seizures. Epilepsia 2003; 44: 228-235.

60. Barnes P, Powell-Griner E, McFann K, Nahin R. The use of complementary and alternative medicine in the United States. National Institutes of Health, US Department of Health and Human Services 2004.

61. Pistolese RA. Epilepsy and seizure disorders: a review of literature relative to chiropractic care of children. J Manipulative PhysiolTher 2001; 24: 199-205.

62. Baxendale S. Complementary and Alternative Treatments for Epilepsy 2015; DOI: 10.1002/9781118936979.ch22

63. Boon P, Raedt R, Herdt V, Wyckhuys T, Vonck K. Electrical Stimulation for the Treatment of Epilepsy. American Society for Experimental NeuroTherapeutics 2009; 6: 218-227.

64. DalkilicEB. Neurostimulation Devices Used in Treatment of Epilepsy. Curr Treat Options Neurol 2017; 19: 2-7. 